\title{
Topoisomerase I/II Inhibitor NEV-801
}

National Cancer Institute

\section{Source}

National Cancer Institute. Topoisomerase I/II Inhibitor NEV-801. NCI Thesaurus. Code C128557.

A multi-targeted agent with potential antineoplastic activity. Upon administration, NEV801 appears to selectively inhibit topoisomerase (T opo) I and II, and activates hypoxiainducible factor 1 (HIF-1) transcription and the expression of vascular endothelial growth factor (VEGF) mRNA. NEV-801 is also able to overcome multidrug resistance (MDR) 1mediated resistance. 